\section{Drip Irrigation in California Strawberry Nurseries to Reduce the Incidence of Colletotrichum acutatum in Fruit Production}

\author{
Oleg Daugovish \\ University of California Cooperative Extension, Ventura County, 669 County \\ Square Drive, Suite 100, Ventura, CA 93003
}

\author{
Mark Bolda \\ University of California Cooperative Extension, Santa Cruz County, 1432 \\ Freedom Boulevard, Watsonville, CA 95076
}

Sukhwinder Kaur

Department of Plant Pathology, University of California, Davis, CA 95616-8680

Maren J. Mochizuki

University of California Cooperative Extension, Ventura County, 669 County

Square Drive, Suite 100, Ventura, CA 93003

\begin{abstract}
Daniel Marcum
University of California Cooperative Extension, P.O. Box 9, 44218 A Street, McArthur, CA 96056
\end{abstract}

Lynn Epstein ${ }^{1}$

Department of Plant Pathology, University of California, Davis, CA 95616-8680

Additional index words. anthracnose, crown, cultural control of disease, Fragaria $\times$ anassasa, daughter plant, quantitative PCR, sprinkler irrigation

\begin{abstract}
Strawberry anthracnose caused by Colletotrichum acutatum is often asymptomatic on plants in sprinkler-irrigated nurseries but destructive after transplantation into fruiting fields. This study evaluated the impact of strawberry nursery sprinkler and drip irrigation in the presence or absence of $C$. acutatum on post-transplantation plant growth, mortality, and fruit yield in fruiting fields in California. In a 2005 nursery at Tulelake, CA, dip infestation of mother plants with $C$. acutatum reduced early-season mother plant canopy size by $21 \%$ and delayed runner production in mother plants but otherwise had no obvious disease symptoms. In comparison with sprinkler-irrigated treatments in the nursery, drip irrigation of infested nursery plots reduced plant losses in fruit production fields by $86 \%$ at Watsonville, $\mathrm{CA}$, in 2005 and $50 \%$ and $75 \%$ at $\mathrm{Oxnard}$, $\mathrm{CA}$, in 2005 and 2008. Transplants from infested nursery treatments had a $33 \%$ to $60 \%$ smaller canopy and $11 \%$ to $\mathbf{4 2 \%}$ lower yield than transplants from uninfested nursery treatments. However, transplant canopy size and yield from the infested and then dripirrigated nursery treatment were similar to the sprinkler-irrigated, non-infested nursery treatment. Quantitative polymerase chain reaction measurements of $C$. acutatum in crown tissue of fruiting field plants seven weeks after transplanting showed significantly more $C$. acutatum $(\approx 11 \times)$ in their crowns in sprinkler-irrigated than drip-irrigated, infested nursery transplant treatments. During the course of fruit production, the amount of $C$. acutatum in crown tissue increased in all treatments. However, at the end of the fruit season, there was still significantly more $(\approx 8 \times) C$. acutatum in the crowns of the plants produced by sprinkler irrigation than by drip irrigation in the nursery. These data suggest that if $C$. acutatum is present in the nursery, drip irrigation can reduce subsequent plant stunting and yield losses in strawberry production fields.
\end{abstract}

Received for publication 16 Nov. 2011. Accepted for publication 17 Jan. 2012.

We thank Conroy Farms, University of Calif. Hansen Trust, California Strawberry Commission, University of Calif. Core Issues Grants, and University of Calif. Intermountain Research and Extension Center for financial support and R. Kim for excellent technical assistance.

${ }^{1}$ To whom reprint requests should be addressed; e-mail lepstein@ucdavis.edu. in a greenhouse followed by a generation in pathogen-free soil in a screenhouse and finally a series of field-grown generations in conditions that promote runner plant production. In early generations of vegetative propagation, mothers produce $\approx 100$ daughters each, which declines to $\approx 30$ daughters each in the final multiplication in a high-elevation (greater than $1000 \mathrm{~m}$ ) nursery. At high elevation, the shortening days in August and September stimulate flower bud initiation and facilitate dormancy, and the cool fall temperatures stimulate vigor for early transplantation into coastal fruit production areas in California (Strand, 2008).

Colletotrichum acutatum Simmonds causes anthracnose of strawberry in California and is an internationally regulated pest (EPPO, 2004). The disease is generally asymptomatic in the nursery, but after planting infected transplants into fruiting fields, the plants can be stunted and die. Also, fruit can develop lesions and be unmarketable (Koike and Browne, 2008; Smith, 2008). Consequently, although strawberry anthracnose is only an intermittent problem in California fruiting fields, it is of constant concern in nurseries because nursery plants with the pathogen cause disease outbreaks in fruiting fields for which fruit growers demand compensation from nurseries.

Hot water dips of mother plants are sometimes used in early nursery generations to control nematodes and C. acutatum, but the strategy is not used in the high-elevation generation destined for fruiting fields because hot water inhibits vigor (Koike and Browne, 2008) and has the potential to spread Xanthomonas fragariae, an internationally regulated pest (Clover et al., 2010). Fungicide dips or water-wash treatments may reduce severity of $C$. acutatum but do not completely eliminate the pathogen (Daugovish et al., 2008; Johnson et al., 2006; Paredes and Munoz, 2002). Because almost all nurseries use sprinkler irrigation, which is conducive for dissemination and infection of Colletotrichum species, nurseries routinely spend over $\$ 1200$ per ha for fungicides as a preventive treatment for $C$. acutatum.

Anthracnose in strawberry caused by $C$. acutatum is difficult to control, partly because some isolates have a wide host range on crops and weeds (Freeman et al., 2001; Peres et al., 2005) and the pathogen can survive in soil on crop debris (Feil et al., 2003; Urena-Padilla et al., 2001). Because C. acutatum conidia are transported by splashing water (Ntahimpera et al., 1997), and water on the leaf surface provides a conducive environment for germination and infection, we postulated that drip irrigation in the nursery would reduce the impact of $C$. acutatum in fruiting fields. The objective of this study was to evaluate the impact of irrigation method and the presence of pathogen pressure in a high-elevation strawberry nursery on subsequent performance of transplants in fruiting fields in California.

\section{Materials and Methods}

valued at $\approx \$ 1.8$ billion (Calif. Dept. of Food and Ag., 2010). Nearly all (greater than $95 \%$ ) transplants originate from individual axenic tissue-culture plants that are used to produce daughters in hanging pots

Each year, California strawberry nurseries transplant "mother" plants into 1,000 ha to produce over one billion runner plant (daughters) for either out-of-state sale or for 15,620 ha of California fruit production,

Growth of nursery transplants. In both years, transplants were produced in Manteca, $\mathrm{CA}$, harvested without leaves, and stored at 
$-2{ }^{\circ} \mathrm{C}$ before use as mother plants in an experimental high-elevation nursery at the Intermountain Research and Extension Center (IREC) at Tulelake, CA (1242 m elevation). In 2005, before the experiment was started, the Tulebasin mucky silty clay loam soil was fumigated with $330 \mathrm{~kg} \cdot \mathrm{ha}^{-1} 67: 33$ methyl bromide/chloropicrin on 5 Apr. Four replicated nursery treatments were used in each year: 1) mother plants dip-infested with C. acutatum and sprinkler-irrigated; 2) mother plants dip-infested with $C$. acutatum and drip-irrigated; 3) non-infested and sprinklerirrigated; and 4) non-infested and drip irrigated. Mother plants were thawed, infested when indicated by a 5 -min dip of the roots and crowns in a suspension of $2.5 \times 10^{5} \mathrm{C}$. acutatum conidia per milliliter, and immediately planted into replicated plots. In 2005, four, $3.4 \mathrm{~m} \times 9.2-\mathrm{m}$ plots per replicate were planted with cv. Ventana on 26 Apr. 2005 with $2.3 \times 10^{4}$ plants/ha $(\approx 0.9 \mathrm{~m}$ between rows and $0.5-\mathrm{m}$ plant between plants within rows). Four rotary sprinklers and high-flow drip tape with $10-\mathrm{cm}$ distance between emitters were spaced $30 \mathrm{~cm}$ apart for the sprinkler- and drip-irrigated plots, respectively. In 2008, 'Camarosa' plants were planted at IREC on 4 Apr. in 2008 at a density of $9 \times 10^{4}$ plants/ha (35-cm plant spacing) in $1.4-\mathrm{m}$ diameter $\times 25-\mathrm{cm}$ deep bins containing nonfumigated Fordney loamy fine sand soil obtained from uncultivated land adjacent to a commercial nursery near Macdoel, CA; the soil type was selected because it is typical of the high-elevation California strawberry nursery soils. Three randomly assigned replicates per treatment were irrigated by either drip tape in a spiral circle or a central $360^{\circ}$ sprinkler on a $1.5-\mathrm{m}$ post. Plots in both years were spaced with $10 \mathrm{~m}$ between plots to avoid water movement between plots; in 2005 and 2008 , there was barley and gravel between the plots, respectively. Irrigation by both drip and sprinkler was scheduled to maintain conditions of adequate soil moisture at the surface to promote rooting of daughter plants and maximum plant growth. Drip irrigation treatments received only drip irrigation throughout the entire season. At harvest, daughter plants were dug by hand, washed to remove soil, and crowns were sorted. After selection of daughters with crowns that were 7.2 to $10.9 \mathrm{~mm}$ in diameter, the plants were cooled and shipped overnight to production fields. In 2005, we conducted an additional trial designed as a completely randomized design in a sprinklerirrigated plot with 51 blocks with each block having one infested and one non-infested mother plant. These plants were used to measure the impact of infestation early in the season on growth of mother plants and on production of runners (stolons that produce daughter plants).

Plant performance in production fields. In the summers of 2005 and 2008, production fields at Watsonville and Oxnard were flatfumigated with $330 \mathrm{~kg} \cdot \mathrm{ha}^{-1}$ of $67: 33$ methyl bromide:chloropicrin. Afterward, beds were constructed and covered with black lowdensity polyethylene mulch $0.15 \mathrm{~mm}$ thick.
Two drip lines 8-cm deep irrigated four rows of plants at Oxnard and a single drip line irrigated two rows of plants at Watsonville. The plastic was mechanically slit to permit placement of transplants and overhead sprinklers were used to facilitate establishment in the first six weeks after planting (Strand, 2008). We planted into a randomized complete block design with 10 replicates of each of the four nursery treatments, each with eight plants on 8 Oct. 2005 at both locations and 12 replicates each with eight plants on 3 Oct. 2008 at Oxnard. Each treatment was separated by two rows of commercial 'Ventana' strawberry to prevent cross-contamination between plots.

Six and seven weeks after transplanting in 2005 and 2008, respectively, we counted the total number of dead and undersized plants that would be replanted commercially. Canopy area of plants surviving early mortality was calculated using the formula for an ellipse (plant length $/ 2 \times$ plant width $/ 2 \times \pi$ ).

To adjust for replicates that would be replanted as a result of plant mortality or undersize, four acceptably sized surviving plants per replicate were arbitrarily selected on 15 Nov. 2005 and 19 Nov. 2008 for fruit yield evaluation; the other plants in the plot were removed. The weight of marketable and unmarketable fruit yield was recorded for the four plants per plot for the typical harvest period for each region (Jan. to June 2006 and 2009 at Oxnard and Mar. to Sept. 2006 at Watsonville). As a result of early mortality at Oxnard in 2005, four of the sprinkler/infested plots had less than four plants remaining for yield measurements; consequently, six replications were analyzed for this treatment.

Detection and quantification of Colletotrichum acutatum in the daughter plants in the nursery and in the fruiting field. At the indicated sampling times, plants were hand-dug, the soil was removed, the leaves were discarded, and infection by C. acutatum was assessed by either bioassay or when indicated in 2009, quantitative real-time polymerase chain reaction (qPCR). Plants were bioassayed for $C$. acutatum using a freezer technique (Mertely and Legard, 2004). Each trimmed plant, with the crown and roots, was washed, frozen at $-20{ }^{\circ} \mathrm{C}$ for $16 \mathrm{~h}$ to kill the plant tissue, surface-disinfested in $0.62 \%$ sodium hypochlorite for $2 \mathrm{~min}$, and incubated for 8 to $10 \mathrm{~d}$ at $28^{\circ} \mathrm{C}$ on moist sterile towels in a re-sealable plastic bag. Crowns and roots were examined under a dissecting microscope for salmon-colored acervuli and putative positives were confirmed with a compound microscope by observation of the expected size and shape of $C$. acutatum conidia.

For qPCR, DNA was quantified using purified $C$. acutatum DNA as an external standard; DNA was purified from the culture used to infest the mother plants as described in Bhat and Browne (2010). The purity and concentration of the standard DNA was determined spectrophotometrically. DNA was isolated from strawberry crowns using a protocol downsized from the one described by
Brandfass and Karlovsky (2008). After plants from the field were washed in running water, the crown was frozen and lyophilized, the outer bark was scraped off, and the crown tissue was ground in liquid $\mathrm{N}_{2}$ with a mortar and pestle. Forty milligrams of powder was placed in a 2-mL tube with two 4-mm diameter glass beads, $20 \mathrm{mg} 106-\mu \mathrm{m}$ diameter glass beads, and $800 \mu \mathrm{L}$ of Brandfass and Karlovsky (2008) extraction buffer with polyvinylpyrrolidone 40 instead of polyvinylpolypyrolidone. Vials were shaken in a FastPrep system (BioSpec, Bartlesville, OK) for four cycles of $30 \mathrm{~s}$ each. Then, samples were incubated at $42^{\circ} \mathrm{C}$ for $10 \mathrm{~min}$, vortexed, and incubated at $65^{\circ} \mathrm{C}$ for 10 min with mixing every $3 \mathrm{~min}$. After addition of $640 \mu \mathrm{L}$ chloroform:isoamyl alcohol (24:1), samples were vortexed $15 \mathrm{~s}$, incubated on ice for 10 $\mathrm{min}$, and centrifuged at $5000 \mathrm{~g}$ for $10 \mathrm{~min}$. After $480 \mu \mathrm{L}$ of the supernatant was transferred to a $1.5-\mathrm{mL}$ tube containing $194 \mu \mathrm{L} 30 \%(\mathrm{w} / \mathrm{v})$ polyethylene glycol (PEG 6000) and $100 \mu \mathrm{L} 5$ $\mathrm{M} \mathrm{NaCl}$, the tube was mixed and centrifuged for $15 \mathrm{~min}$ at $15,000 \mathrm{~g}$. After the supernatant was discarded, the pellet was washed with $1 \mathrm{~mL}$ $70 \%(\mathrm{v} / \mathrm{v})$ ethanol and centrifuged for $30 \mathrm{~s}$. After removal of the ethanol, the pellet was dried, dissolved in $200 \mu \mathrm{L} 10 \mathrm{mM}$ Tris- $\mathrm{HCl}(\mathrm{pH} 8)$ containing $1 \mathrm{mM}$ EDTA (TE), and stored at $4{ }^{\circ} \mathrm{C}$.

The following primers and probe (from $5^{\prime}$ to $3^{\prime}$ ) were tested by Garrido et al. (2009): ACUT-F1, CGGAGGAAACCAAACTCTA TTTACA; ACUT-R1, CCAGAACCAAGA GATCCGTTG; and 5'Fam - 3' Tamra ACUTPB probe, CGTCTCTTCTGAGTGGCACAA GCAAATAATTAAA. TaqMan ${ }^{\circledR}$ assays (final volume $25 \mu \mathrm{L}$ ) contained $1 \times$ Taqman Universal Master mix AB-0055 (Applied Biosystems, Foster City, CA) with ROX, $300 \mathrm{nM}$ of each primer, $100 \mathrm{nM}$ probe, and $5 \mu \mathrm{L}$ template DNA extract. To assure that PCR inhibitors were removed, both 1:100 and 1:1000 dilutions of template DNA were used. Negative controls without plant extract were included in every run. PCR reactions were conducted at $50^{\circ} \mathrm{C}$ for $2 \mathrm{~min}, 95^{\circ} \mathrm{C}$ for $10 \mathrm{~min}$, and 45 cycles of $95^{\circ} \mathrm{C}$ for $15 \mathrm{~s}$ and $60^{\circ} \mathrm{C}$ for $1 \mathrm{~min}$. PCR was performed in a 7500 Fast RealTime PCR System (Applied Biosystems). The sample cycle threshold values in comparison with the standard were used to calculate the quantity of $C$. acutatum DNA. The absence of PCR inhibitors in the crown extract was assured by the use of the two dilutions of sample DNA and by spiking selected samples with known quantities of standard DNA. C. acutatum in roots was not quantified because there were too many PCR inhibitors as indicated by multiple dilutions of sample DNA and by spiking selected samples with known quantities of standard DNA (data not shown).

Statistical analysis. Except when indicated otherwise, data were analyzed using a general linear mixed model (Version 9.2; SAS Systems, Cary, NC). The model assumption for homogenous variance was checked by the Levene test. The overall error rate for multiple comparisons was controlled by Tukey-Kramer honestly significant difference. To address potential autocorrelation for plant size (measured on the same plants on multiple sampling dates), 
repeated-measures analysis of variance was used. For this analysis, we selected the compound symmetry and heterogeneous compound symmetry covariance models for Watsonville and Oxnard, respectively, based on measures of relative fit of competing covariance models.

\section{Results and Discussion}

Both 'Camarosa' and 'Ventana' are University of California short-day strawberry varieties. Starting in 2002, 'Camarosa' was largely replaced by 'Ventana'. We used 'Camarosa' in the second experiment because it is considered more susceptible to C. acutatum (Seijo et al., 2008) and is a prolific producer of daughter plants in California nurseries.

Growth of the nursery transplants. In the nursery in 2005, mother plants that were dipinfested with $C$. acutatum and then grown under sprinkler irrigation were largely asymptomatic; only one runner lesion was observed in 2005. However, plants that were infested with $C$. acutatum were significantly smaller $(P<0.001)$ with an average of a $21 \%$ reduction in area in the first 12 weeks (Fig. 1). The infested plants also had significantly $(P<0.001)$ fewer runners in the first 12 weeks with $39 \%$ fewer runners than noninfested controls. An analysis of the slope indicated that infested mothers had a significantly $(P=0.0015)$ lower growth rate than the non-infested controls; control mothers increased an average of $49 \pm 2 \mathrm{~cm}^{2}$ per day, whereas the infested plants increased $40 \pm$ $2 \mathrm{~cm}^{2}$ per day. Plant area and the number of runners were significantly correlated $(P<0.001, r=0.72$ and 0.70 for infested and non-infested, respectively). Infested mothers also had a significantly $(P<0.0001)$ lower rate of runner production than the noninfested controls; control mothers produced an average of $3.2 \pm 0.1$ new runners per week, whereas the infested plants added $2.1 \pm$ 0.1 runners per week. These data indicate that although the disease is asymptomatic in the nursery, infection can have a negative impact on nursery productivity. Other than a reduction in size and runner production, no other symptoms of $C$. acutatum infection were observed in nursery daughter plants at IREC in either 2005 or 2008 . Other researchers (Freeman et al., 2001; Leandro et al., 2001) have observed asymptomatic infections. No adverse impacts of drip irrigation in the nursery on plant production were observed.

In 2005 there were no significant differences in yield of daughter plants between drip and sprinkler irrigation $\left(62.4\right.$ and $76.4 / \mathrm{m}^{2}$, respectively, $P=0.08$ ) (data not shown). In 2008, the infested treatments had $49 \%$ fewer daughters; however, the reduced numbers of daughters were specifically in the small-sized category, whereas production of large- and medium-sized daughters was similar in all treatments (Table 1). In commercial practice, in years in which there is a shortage of plants, small plants are used or in some cases harvested later.
Plant growth in fruiting fields. In the fruiting fields, plants from the infested treatments in the nursery generally grew more slowly than plants from the non-infested treatments (Fig. 2). At Watsonville in 2005, daughter plants from infested, sprinkler-irrigated mothers had a $60 \%$ smaller canopy size in November and a $66 \%$ smaller canopy size in December than plants from infested nursery mothers produced under drip (Fig. 2A). In plants from the non-infested mothers, there was no difference in canopy size between irrigation methods. At Oxnard in 2005-2006 at all sampling dates, plants from drip treatments were similar regardless of whether the mothers were infested (Fig. 2B). Overall, by Jan. 2006, the canopy of plants from infested mothers was $33 \%$ smaller than those from non-infested, suggesting the pathogen slowed plant growth. Plants measured in Nov. 2008 at Oxnard showed a similar pattern; the canopy area of plants from infested mothers was $50 \%$ less than those from non-infested mothers (Fig. 2C). Although plant canopies developed differently in different years and locations, drip irrigation tended to minimize the negative effects of nursery infestation on early-season canopy size in the fruiting field. The differences in canopy development between production areas and years was not unexpected; fall fertilization, in-field chilling, and harvest date can affect plant growth and fruit production between locations and years (Galletta and Bringhurst, 1990).

Plant losses resulting from mortality and poor growth in fruiting fields. Six weeks after transplanting, daughter plants from infested mothers grown with sprinkler irrigation had sevenfold greater mortality at Watsonville in 2005 and two- and fourfold at Oxnard in 2005 and 2008, respectively, compared with daughters from infested mothers produced in drip irrigation (Table 2). In 2005, survival of daughter plants from infested mothers grown with drip irrigation did not differ from the non-infested treatments. In 2008 at Oxnard, in addition to dead plants, plants with diameters less than $7 \mathrm{~cm}$ were considered undersized by grower standards and were also removed because growers would typically replant them; because we could cull our undersized plants, none of these plants was replanted in our trial. The four treatments were separated into three replant groups: daughters of infested mothers that were sprinklerirrigated required significantly more replants, daughters of infested mothers that were dripirrigated required significantly fewer replants, and daughters of non-infested mothers required no replants (Table 2). In the production field, replants are not always readily available, add to production costs, and usually lag in the fruiting cycle, thereby producing less profit (Larson et al., 2009). Our results suggest that

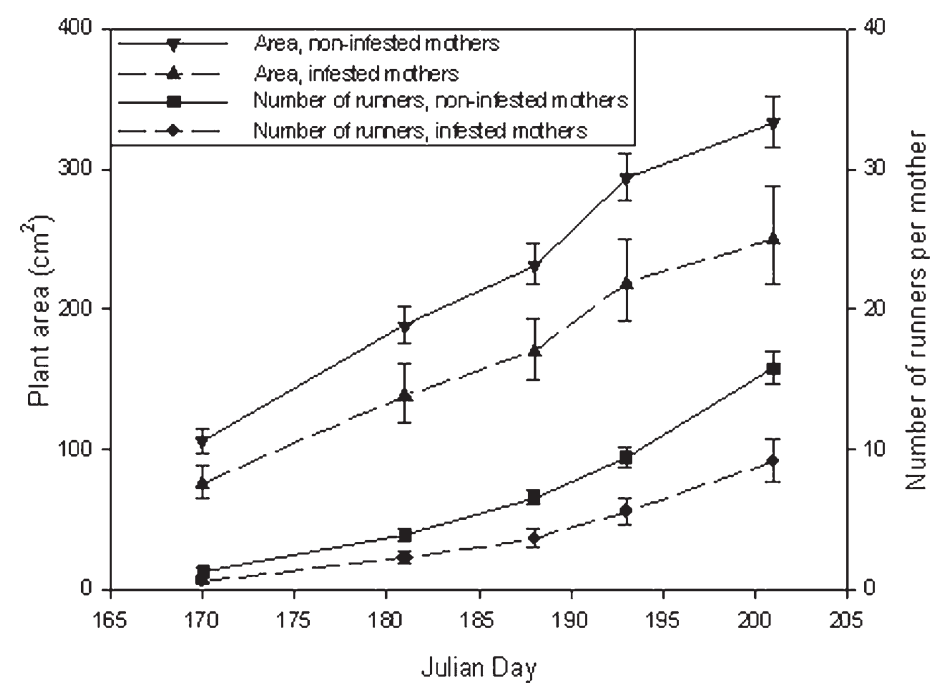

Fig. 1. Effect of Colletotrichum acutatum on growth and runner production of 'Ventana' strawberry plants in a high-elevation nursery planting with sprinkler irrigation. Data were log-transformed to meet the assumption of additivity for multivariate analysis of variance. Back-transformed means and $95 \%$ confidence intervals are shown. $\mathrm{n}=51$.

Table 1. Effect of infestation of mother plant roots with Colletotrichum acutatum and sprinkler vs. drip irrigation in the nursery on yield of 'Camarosa' daughter plants in the nursery in 2008.

\begin{tabular}{lccccc}
\hline Treatment of mothers with & Irrigation during & \multicolumn{4}{c}{ Daughters (no. per $\left.\mathrm{m}^{2}\right)^{\mathrm{y}}$} \\
\cline { 3 - 6 } C. acutatum at planting & daughter production & Total & Large & Medium & Small \\
\hline Infested & Sprinkler & $167 \mathrm{~b}$ & $22 \mathrm{a}$ & $62 \mathrm{a}$ & $83 \mathrm{~b}$ \\
Infested & Drip & $147 \mathrm{~b}$ & $22 \mathrm{a}$ & $37 \mathrm{a}$ & $88 \mathrm{~b}$ \\
Not infested & Sprinkler & $248 \mathrm{a}$ & $31 \mathrm{a}$ & $77 \mathrm{a}$ & $140 \mathrm{ab}$ \\
Not infested & Drip & $263 \mathrm{a}$ & $28 \mathrm{a}$ & $100 \mathrm{a}$ & $145 \mathrm{a}$ \\
\hline
\end{tabular}

${ }^{\mathrm{z}}$ At harvest on 1 Oct. 2008, daughters were classified into three size groups based on crown diameter: large, 11.0 to $17.6 \mathrm{~mm}$; medium, 7.2 to $10.9 \mathrm{~mm}$; and small, 2.5 to $6.9 \mathrm{~mm}$.

${ }^{y}$ Data met the assumption of homogeneity of variance (Levene $P>0.05$ ). Within a column, means followed by the same letter were not significantly different by Tukey's honestly significant difference, $\alpha=0.05$. 
plants from infested mothers grown with drip irrigation instead of sprinkler in the nursery are less likely to die or be undersized and thus require replanting.

Fruit yields in production fields. A twoway analysis of variance of 2008 yields indicated no significant interaction of the two factors $(P=0.36)$ but a significant effect of both infestation of nursery plants $(P<0.0001)$ with $C$. acutatum and irrigation method $(P=0.048)$. Yields of plants from the non-infested drip or sprinklerirrigated nursery mothers were similar and generally greater than yields from plants from infested mothers (Table 3). However, plants from infested mothers at Watsonville in 2006 and at Oxnard in 2009 that were drip-irrigated had fruit yields similar to the non-infested sprinkler treatment, consistent with drip irrigation decreasing the negative impact of C. acutatum on plant growth in the nursery and in production fields. Interestingly, even after undersized plants were removed, there was a highly significant slope $(P=0.0001)$ of a linear regression of fruit yield on plant area at 5.4 weeks $\left(r^{2}=0.46\right)$, i.e., plant area at 5.4 weeks after planting predicted almost half of the variance of total cumulative yield (data not shown).

Colletotrichum acutatum infection in daughter plants in the nursery and after fruit production. We used two assays to monitor $C$. acutatum in the daughters: a bioassay in which the fungus is scored as present or absent (Table 4) and a qPCR assay with Taqman probes and C. acutatum DNA as an external standard (Tables 4 and 5). At the end of nursery production, there was very low infection $(0 \%$ to $2 \%)$ in the non-infested treatments and high incidence ( $78 \%$ to $82 \%)$ in the infested treatments. By bioassay, on a wholeplant basis, the percentage incidence in the infested and either sprinkler- or drip-irrigated was indistinguishable. However, the bioassay indicated that significantly more of the daughters from the infested and sprinkler-irrigated were infected in both the crown and the roots than in the drip-irrigated. At seven weeks after transplanting when the plots were thinned to four plants per replicate, the culled plants were arbitrarily assigned for analysis by either bioassay or qPCR. In terms of percentage infection, results by bioassay and qPCR were indistinguishable at seven weeks after transplanting. However, qPCR expressed as nanograms $C$. acutatum DNA per gram dry weight crown tissue clearly demonstrated that seven weeks after planting, plants that were produced in infested plots with drip irrigation had significantly $(\alpha=0.05)$ less $C$. acuatum in their crowns than plants that were produced in sprinkler-irrigated plots (Table 5). Daughters from infested mothers grown with sprinkler irrigation had significantly more $(\approx 11 \times)$ C. acutatum than daughters from drip-irrigated plots. During the course of fruit production, the amount of C. acutatum in crown tissue increased in all treatments. Nonetheless, at the end of the fruit season, there was still significantly more $(\approx 8 \times)$ C. acutatum in the crown tissue of the daugh- ters that had been produced under sprinkler than under drip in the nursery.

Implications of the research for disease control. There is much anecdotal evidence that asymptomatic but infected nursery transplants are an economically important source of $C$. acutatum in strawberry fruiting fields (Howard et al., 1992; Smith, 2008; UrenaPadilla et al., 2001) and that control of Colletotrichum spp. in the nursery is critical for disease control in fruiting fields (McInnes et al., 1992). C. acutatum can grow as an endophyte in strawberry plants (Freeman et al., 2001), conidiate on symptomless leaves (Leandro et al., 2001) and, similar to rain splash, be dispersed by sprinkler irrigation, which also provides a conducive environment for germination and infection of Colletotrichum spp. conidia (Madden, 1992; Madden and Wilson, 1997). We provide empirical data
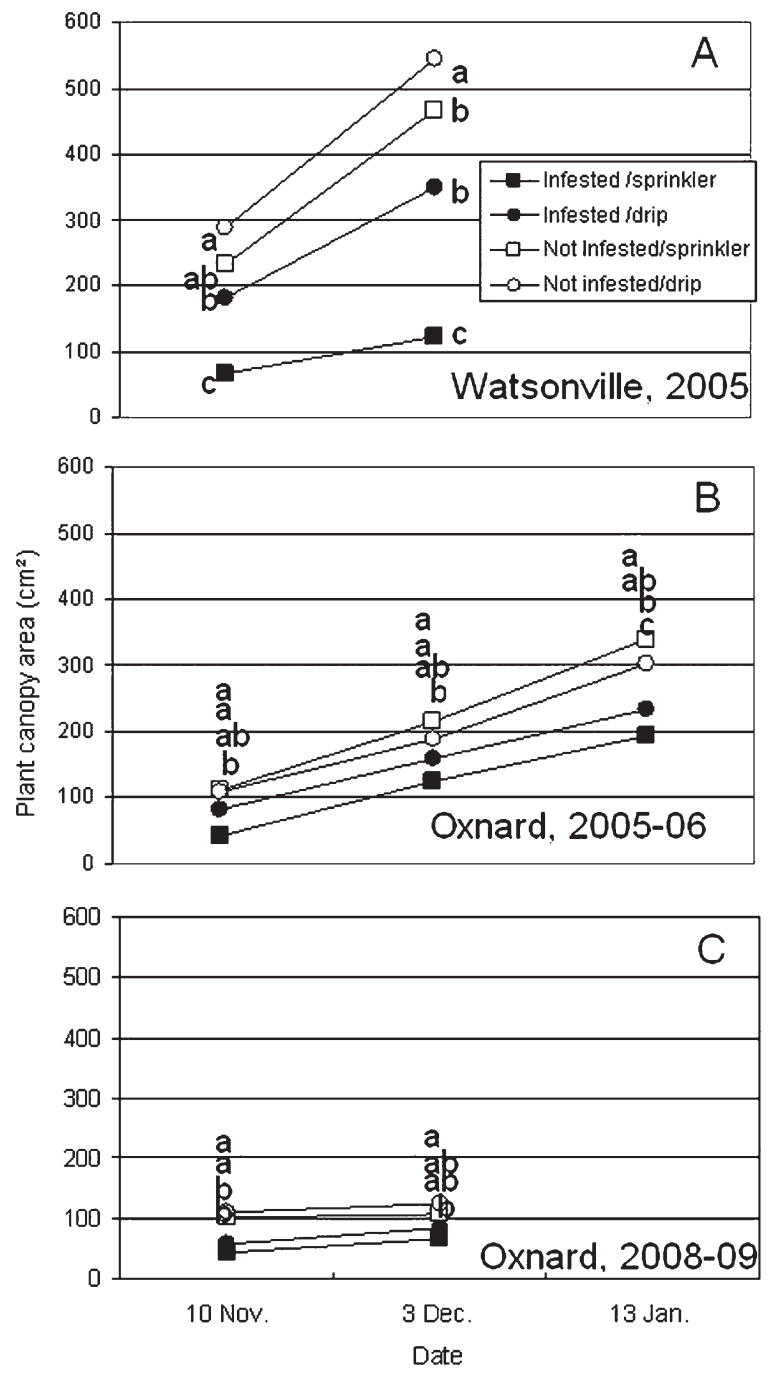

Fig. 2. Effect of nursery treatment on canopy area of surviving strawberry daughter plants before fruit production. Within a location/year, means within a sampling date followed by the same letter are not significantly different ( $\alpha=0.05$; Tukey-Kramer honestly significant difference).

Table 2. Effect of nursery production treatment on either mortality or severe stunting of strawberry daughter plants in fruit production fields. ${ }^{z}$

\begin{tabular}{lccc}
\hline & \multicolumn{2}{c}{ Dead or undersized (\%) $)^{\mathrm{y}}$} \\
\cline { 2 - 4 } Nursery treatment & Watsonville & Oxnard \\
\cline { 2 - 4 } 5 Nov. 2005 & $29 \mathrm{a}$ & $40 \mathrm{a}$ & 24 Oct. 2008 \\
\hline Infested/sprinkler & $4 \mathrm{~b}$ & $20 \mathrm{~b}$ & $6 \mathrm{~b}$ \\
Infested/drip & $1 \mathrm{~b}$ & $15 \mathrm{~b}$ & $0 \mathrm{c}$ \\
Not infested/sprinkler & $2 \mathrm{~b}$ & $14 \mathrm{~b}$ & $0 \mathrm{c}$ \\
Not infested/drip & Colt. 2005 \\
\hline
\end{tabular}

${ }^{\mathrm{z}}$ Mother plants were dip-infested with Colletotrichum acutatum and planted in a nursery at Tulelake, CA, in April and then sprinkler- or drip-irrigated until daughters were harvested and planted in the production fields in October.

${ }^{\mathrm{y}}$ Mortality was recorded for eight plants per replicate six weeks after transplanting; there were 10 and 12 replicates in 2005 and 2008, respectively. Undersized plants were less than $7 \mathrm{~cm}$ in diameter. Within a column, means followed by the same letter were not significantly different by Fisher's exact test with a Bonferroni adjustment for six pairwise comparisons $(P=0.0083$ for $\alpha=0.05)$. 
that in the presence of $C$. acutatum in the nursery, drip rather than sprinkler irrigation provides a less conducive environment for C. acutatum and ultimately results in daughter plants with less fungal growth. Previously, Coelho et al. (2008) showed that in the presence of $C$. acutatum in fruiting fields, there were significantly fewer blighted flowers and rotten fruit in plots with drip rather than overhead irrigation. Although rainfall is critical for Colletotrichum spp. in natural environments, summer rainfall in Tulelake

probably did not affect this experiment because rain provided less than $2 \%$ of ETo (Calif. Irrigation Management Information System, 1982) in both years in the 3-month period from July to September when most growth in the nursery occurs.

Real-time PCR is increasingly used for both detection and quantification of fungi in plant tissue (Debode et al., 2009; Garrido et al., 2009). Previously, Garrido et al. (2009) used qPCR to quantify $C$. acutatum in artificially inoculated crowns. Because strawberry

Table 3. Effect of nursery production treatment on post-transplantation strawberry fruit yield.

\begin{tabular}{lccr}
\hline & \multicolumn{2}{c}{ Total marketable yield per plant $(\mathrm{g})^{\mathrm{z}}$} \\
\cline { 2 - 4 } Nursery treatment & Watsonville & 2006 & Oxnard \\
\cline { 2 - 4 } & 2006 & $403 \mathrm{~b}$ & $612 \mathrm{c}$ \\
Infested/sprinkler & $473 \mathrm{ab}$ & $568 \mathrm{~b}$ & $720 \mathrm{bc}$ \\
Infested/drip & $402 \mathrm{ab}$ & $899 \mathrm{a}$ & $836 \mathrm{ab}$ \\
Not infested/sprinkler & $548 \mathrm{a}$ & $769 \mathrm{a}$ & $876 \mathrm{a}$ \\
Not infested/drip & & &
\end{tabular}

${ }^{\mathrm{z}}$ Marketable yield was measured on the four plants after thinning from January to June at Oxnard and from April to September at Watsonville. Within a column, means followed by the same letter were not significantly different for a one-way analysis ( $\alpha=0.05$; Tukey-Kramer honestly significant difference). transplants in California are transported without leaves, C. acutatum DNA in the crowns provides a good proxy for the extent of internal inoculum. Our data provide empirical evidence that strawberry transplants with a pre-existing $C$. acutatum infection are significantly more likely to die early in the production season, be stunted, and/or to have reduced fruit yield. Our data further indicate that in the presence of $C$. acutatum in nursery soil, drip irrigation can significantly decrease the severity of the infection in nursery transplants and thereby have a positive effect on survival, plant growth, and fruit yield.

Although the California strawberry nursery industry predominantly uses sprinkler irrigation, drip is being adopted; one grower uses a combination of drip and sprinklers, and two others use drip irrigation in tunnels, which preclude use of sprinklers. Although material and labor costs for drip irrigation are greater than for sprinkler irrigation, conversion to drip may have compensating savings with reduced water use and less need for irrigation runoff management.

Table 4. Effect of infestation of strawberry mother plants with Colletotrichum acutatum conidia and sprinkler vs. drip irrigation in the nursery on the incidence of C. acutatum infection in crowns of daughter plants before and after fruit production. ${ }^{z}$

\begin{tabular}{|c|c|c|c|c|c|c|}
\hline \multirow{2}{*}{$\begin{array}{l}\text { Treatment of } \\
\text { mothers with } \\
\text { C. acutatum } \\
\text { at planting }\end{array}$} & \multirow{2}{*}{$\begin{array}{c}\text { Irrigation during } \\
\text { daughter } \\
\text { production }\end{array}$} & \multicolumn{3}{|c|}{$\begin{array}{l}\text { Daughters infected with } C \text {. acutatum } \\
\text { (\% by bioassay) }\end{array}$} & \multicolumn{2}{|c|}{$\begin{array}{c}\text { Daughters infected with } C \text {. acutatum in crown } \\
(\% \text { by quantitative PCR })^{\mathrm{v}}\end{array}$} \\
\hline & & $\begin{array}{l}\text { Either crowns } \\
\text { or roots }\end{array}$ & $\begin{array}{l}\text { Both crowns } \\
\text { and roots }\end{array}$ & $\begin{array}{c}7 \text { weeks after transplanting, } \\
\text { on either crowns } \\
\text { or roots }(\%)^{x, w}\end{array}$ & $\begin{array}{l}7 \text { weeks after } \\
\text { ransplanting }\end{array}$ & $\begin{array}{l}\text { After fruit } \\
\text { production }^{u}\end{array}$ \\
\hline Infested & Sprinkler & $82 \mathrm{a}$ & $51 \mathrm{a}$ & $100 \mathrm{a}$ & $95 \mathrm{a}$ & $92 \mathrm{a}$ \\
\hline Infested & Drip & $78 \mathrm{a}$ & $29 \mathrm{~b}$ & $83 \mathrm{a}$ & $86 \mathrm{a}$ & $70 \mathrm{a}$ \\
\hline Not infested & Sprinkler & $2 \mathrm{~b}$ & $0 \mathrm{v}$ & $8 \mathrm{~b}$ & $8 \mathrm{~b}$ & $42 \mathrm{~b}$ \\
\hline Not infested & Drip & $0 \mathrm{~b}$ & $0 \mathrm{v}$ & $0 \mathrm{~b}$ & $0 \mathrm{~b}$ & $17 \mathrm{~b}$ \\
\hline
\end{tabular}

${ }^{\mathrm{z}}$ At planting in the nursery in 2008, mother plants were either dipped into a suspension of Colletotrichum acutatum conidia or not and either propagated under drip or sprinkler irrigation. Plants had no signs of anthracnose in the nursery. After harvest at the nursery, daughters suitable for transplantation (crowns with diameter from 7.2-10.9 mm) were selected and either assayed or transplanted into a fruiting field with a completely randomized block design with 12 replicate blocks, each with eight plants (four plants on each of two diagonal rows) per block. Means followed by the same letter are not different $(\alpha=0.05)$. Data were analyzed by Tukey's honestly significant difference except when indicated otherwise.

${ }^{y}$ The percentage infected was determined by a bioassay of 15 plants from each of three replicate bins.

${ }^{\mathrm{x}} \mathrm{After} 7$ weeks in the fruiting field, plants were thinned to four plants per replicate. One thinned plant per replicate was arbitrarily assigned for bioassay and two for quantitative polymerase chain reaction.

${ }^{\text {w}}$ Data were analyzed by contingency analysis. Pairwise comparisons were made by Fisher's exact test using the Bonferroni adjustment for six comparisons $(P=$ 0.0083 for $\alpha=0.05$ ).

${ }^{\mathrm{v}}$ C. acutatum DNA in crowns was determined by real-time polymerase chain reaction (PCR) with Taqman technology.

${ }^{u}$ All four plants per replicate from each infested treatment were analyzed. One plant per replicate from each non-infested treatment was randomly selected and analyzed.

Table 5. Effect of infestation of strawberry mother plants with Colletotrichum acutatum conidia and sprinkler vs. drip irrigation in the nursery on the quantity of $C$. acutatum in crowns of daughter plants before and after fruit production. ${ }^{2}$

\begin{tabular}{|c|c|c|c|c|c|}
\hline \multirow[b]{3}{*}{$\begin{array}{l}\text { Treatment of mothers } \\
\text { with } C \text {. acutatum at planting }\end{array}$} & \multirow[b]{3}{*}{$\begin{array}{l}\text { Irrigation during } \\
\text { daughter production }\end{array}$} & \multicolumn{4}{|c|}{ ng C. acutatum DNA per g dry wt crown tissue ${ }^{y}$} \\
\hline & & \multicolumn{2}{|c|}{ All plants } & \multicolumn{2}{|c|}{ Infected plants only } \\
\hline & & $\begin{array}{l}7 \text { weeks after } \\
\text { transplanting }\end{array}$ & $\begin{array}{c}\text { After fruit } \\
\text { production }\end{array}$ & $\begin{array}{l}7 \text { weeks after } \\
\text { transplanting }\end{array}$ & $\begin{array}{c}\text { After fruit } \\
\text { production }^{\mathrm{w}}\end{array}$ \\
\hline Infested & Drip & $0.7 \mathrm{~b}$ & $6 \mathrm{~b}$ & $2 \mathrm{~b}$ & $17 \mathrm{ab}$ \\
\hline Not infested & Sprinkler & $0.04 \mathrm{~b}$ & $0.3 \mathrm{c}$ & $0.7 \mathrm{~b}$ & $0.9 \mathrm{~b}$ \\
\hline Not infested & Drip & $0.00 \mathrm{~b}$ & $0.1 \mathrm{c}$ & $\mathrm{NA}^{\mathrm{v}}$ & $0.7 \mathrm{~b}$ \\
\hline
\end{tabular}

${ }^{\mathrm{z}}$ At planting in the nursery in 2008, mother plants were either dipped into a suspension of Colletotrichum acutatum conidia or not and either propagated under drip or sprinkler irrigation. Plants had no signs of anthracnose in the nursery. After harvest at the nursery, daughters suitable for transplantation (crowns with diameter from 7.2-10.9 mm) were selected and either assayed or transplanted into a fruiting field with a completely randomized block design with 12 replicate blocks, each with eight plants (four plants on each of two diagonal rows) per block. Within a column, means followed by the same letter were not significantly different by Tukey's honestly significant difference, $\alpha=0.05$.

${ }^{y}$ C. acutatum DNA in crowns was determined by real-time polymerase chain reaction with Taqman technology. Data were analyzed as the log $(1+\mathrm{ng} C$. acutatum DNA) per gram crown tissue. Back-transformed values are shown.

${ }^{\mathrm{x}}$ After seven weeks in the fruiting field, plants were thinned to four plants per replicate. Of the thinned plants, one and two plants from the noninfested and infested mother plant treatments, respectively, per replicate were assayed.

${ }^{w}$ All four plants per replicate from each infested treatment was analyzed. One plant per replicate from each non-infested treatment was randomly selected and analyzed.

"Not applicable; no infected plants were detected. 
The potential for drip to reduce disease risk could result in less fungicide use. Use of drip irrigation in the nursery may also help minimize the negative effects of other waterdispersed pathogens as we have demonstrated here for $C$. acutatum on strawberry.

\section{Literature Cited}

Bhat, R.G. and G.T. Browne. 2010. Specific detection of Phytophthora cactorum in diseased strawberry plants using nested polymerase chain reaction. Plant Pathol. 59:121-129.

Brandfass, C. and P. Karlovsky. 2008. Upscaled CTAB-based DNA extraction and real-time PCR assays for Fusarium culmorum and $F$. graminearum DNA in plant material with reduced sampling error. Intl. J. Mol. Sci. 9:23062321.

Calif. Dept. of Food and Ag. 2010. Calif. Ag. Res Dir.: 68. 31 Mar. 2011.<http://www.cdfa.ca.gov/ Statistics/>.

Calif. Irrigation Management Information System. 1982. 8 Oct. 2011. <http://wwwcimis.water.ca. gov/cimis/>.

Clover, G., S. Hammons, and J.G. Unger. 2010. International diagnostic protocols for regulated plant pests. EPPO Bulletin 40:24-29.

Coelho, M.V.S., F.R. Palma, and A.C. Café-Filho. 2008. Management of strawberry anthracnose by choice of irrigation system, mulching material and host resistance. Intl. J. Pest Mgt. 54:347-354

Daugovish, O., W. Gubler, and H. Su. 2008. Pre-plant fungicide dips of strawberry transplants to control anthracnose caused by Colletotrichum acutatum in California. HortTechnology 9:317-323.

Debode, J., W. Van Hemelrijck, S. Baeyen, P. Creemers, K. Heungens, and M. Maes. 2009. Quantitative detection and monitoring of $\mathrm{Col}$ letotrichum acutatum in strawberry leaves using real-time PCR. Plant Pathol. 58:504-514.
EPPO. 2004. Diagnostic protocols for regulated pests. Glomerella acutata. EPPO Bulletin 34: 193-199.

Feil, W.S., E.E. Butler, J.M. Duniway, and W.D. Gubler. 2003. The effects of moisture and temperature on the survival of Colletotrichum acutatum on strawberry residue in soil. Can. J. Plant Pathol. 25:362-370.

Freeman, S., S. Horowitz, and A. Sharon. 2001. Pathogenic and nonpathogenic lifestyles in Colletotrichum acutatum from strawberry and other plants. Phytopathology 91:986-992.

Galletta, G.J. and R.S. Bringhurst. 1990. Strawberry management, p. 83-156. In: Galletta, G.J. and D.G. Himelrick (eds.). Small fruit crop management. Prentice-Hall, Upper Saddle River, NJ.

Garrido, C., M. Carbú, F.J. Fernández-Acero, N. Boonham, A. Colyer, J.M. Cantoral, and G. Budge. 2009. Development of protocols for detection of Colletotrichum acutatum and monitoring of strawberry anthracnose using realtime PCR. Plant Pathol. 58:43-51.

Howard, C.M., J.L. Maas, C.K. Chandler, and E.E. Albregts. 1992. Anthracnose of strawberry caused by the Colletotrichum complex in Florida. Plant Dis. 76:976-981.

Johnson, A.W., D.W. Simpson, and A. Berrie. 2006. Hot water treatment to eliminate Colletotrichum acutatum from strawberry runner cuttings. Acta Hort. 708:255-258.

Koike, S.T. and G.T. Browne. 2008. Strawberry anthracnose. Univ. Calif. Intl. Pest Mgt. Guidelines: Strawberry. Agr. Nat. Res. Publ. 34689 July 2011. <http://ucipm.ucdavis.edu/PMG/ r734101011.html>. Accessed July 9, 2011.

Larson, K.D., O. Daugovish, and D.V. Shaw. 2009. Optimizing strawberry production and fruit quality with use of protected culture in southern California. Acta Hort. 842:171-176.

Leandro, L.F.S., M.L. Gleason, F.W. Nutter, Jr., S.N. Wegulo, and P.M. Dixon. 2001. Germination and sporulation of Colletotrichune acutatum on symptomless strawberry leaves. Phytopathology 91:659-664.

Madden, L.V. 1992. Rainfall and the dispersal of fungal spores. Adv. Plant Pathol. 8:39-79.

Madden, L.V. and L.L. Wilson. 1997. Effect of rain distribution alteration of splash dispersal of Colletotrichum acutatum. Phytopathology 87:649-655.

McInnes, T.B., L.L. Black, and J.M. Gatti, Jr. 1992. Disease-free plants for management of strawberry anthracnose crown rot. Plant Dis. 76: 260-264.

Mertely, J.C. and D.E. Legard. 2004. Detection, isolation, and pathogenicity of Colletotrichum spp. from strawberry petioles. Plant Dis. 88 : 407-412.

Ntahimpera, N., L.V. Madden, and L.L. Wilson. 1997. Effect of rain distribution alteration on splash dispersal of Colletotrichum acutatum. Phytopathology 87:649-655.

Paredes, B.S.G. and F.R. Munoz. 2002. Effect of different fungicides in the control of Colletotrichum acutatum, causal agent of anthracnose crown rot in strawberry plants. Crop Prot. 21: $11-15$.

Peres, N.A., L.W. Timmer, J.E. Adaskaveg, and J.C. Correll. 2005. Lifestyles of Colletotrichum acutatum. Plant Dis. 89:784-796.

Seijo, T.E., C.K. Chandler, J.C. Merteley, C. Moyer, and N.A. Peres. 2008. Resistance of strawberry cultivars and advanced selections to anthracnose and Botrytis fruit rots. Proc. Fla. State Hort. Soc. 121:246-248.

Smith, B.J. 2008. Epidemiology and pathology of strawberry anthracnose: A North American perspective. HortScience 43:69-73.

Strand, L. 2008. Integrated pest management for strawberries. 2nd Ed. Univ. of Calif. Statewide Intl. Pest Mgt. Project, Agr. Nat. Res. Publ. 3351.

Urena-Padilla, A.R., D.J. Mitchell, and D.E. Legard. 2001. Oversummer survival of inoculum for Colletotrichum crown rot in buried strawberry crown tissue. Plant Dis. 85:750-754. 